Required Disclosure and Corporate Governance

Author(s): Merritt B. Fox

Source: Law and Contemporary Problems, Vol. 62, No. 3, Challenges to Corporate Governance (

Summer, 1999), pp. 113-127

Published by: Duke University School of Law

Stable URL: http://www.jstor.org/stable/1192228

Accessed: 14-10-2015 16:18 UTC

Your use of the JSTOR archive indicates your acceptance of the Terms \& Conditions of Use, available at http://www.jstor.org/page/ info/about/policies/terms.jsp

JSTOR is a not-for-profit service that helps scholars, researchers, and students discover, use, and build upon a wide range of content in a trusted digital archive. We use information technology and tools to increase productivity and facilitate new forms of scholarship. For more information about JSTOR, please contact support@jstor.org. 


\title{
REQUIRED DISCLOSURE AND CORPORATE GOVERNANCE
}

\author{
MERRITT B. FOX * \\ I \\ INTRODUCTION
}

One of the most distinctive features of U.S. business law is the stringent requirements of ongoing disclosure imposed on issuers of publicly traded securities. This scheme usually has been justified as necessary to protect investors

\footnotetext{
Copyright $@ 2000$ by Merritt B. Fox

This article is also available at http://www.law.duke.edu/journals/62LCPFox.

* Professor of Law, University of Michigan.
}

The author wishes to express appreciation for helpful comments on an earlier draft of this article by participants at the Conference on Comparative Corporate Governance at the Max-Planck Institute in May 1997.

An earlier version of this article appears in COMPARATIVE CORPORATE GOVERnANCE: THE StATE OF THE ART AND EMERging RESEARCH 701 (Klaus J. Hopt et. al. eds., 1998). Copyright @ 1998 by Clarendon Press, Oxford. Used with permission.

1. The United Kingdom is a convenient benchmark for demonstrating that U.S. requirements are more stringent than those in any other country because the SEC considers the United Kingdom's disclosure requirements more similar to those of the United States than are any other country's except Canada's. See Facilitation of Multinational Securities Offerings, Securities Act Release No. IS-55, 32 S.E.C. Docket 707 (Feb. 28, 1985). Nevertheless, a detailed comparison of U.S. and U.K. disclosure requirements for companies that issue equity securities reveals that the United States requires significantly more information. Differences in the requirements include the amount of detail about the nature of the issuer's business; data concerning the results of the different lines of business in which the issuer participates; discussion of trends that are identified by management and may affect the issuer's future liquidity, capital needs, or operating results; and information about management compensation and share ownership. See SEC Proposals to Facilitate Multinational Securities Offerings: Disclosure Requirements in the United States and the United Kingdom, 19 INT'L L. \& POL. 457, 459-68 (1987); see also GEORgE BENSTON, CORPORATE FINANCIAL DisClosure IN THE UK AND THE USA 20-21, 37 (1976); SECURITIES \& EXCHANGE COMMISSION, REPORT OF THE STAFF OF THE U.S. SECURITIES and Exchange Commission to the Senate CommitTeE on Banking, Housing and UrbaN AFFAIRS AND THE HOUSE COMMITTEE ON ENERGY AND COMMERCE ON THE INTERNATIONALIZATION OF THE SECURITIES MARKETS III-91-92 (1987) (hereinafter SEC INTERNATIONALIZATION REPORT). European countries, in general, put much less emphasis on full disclosure. See Peter Widmer, The U.S. Securities Laws-Banking Law of the World? (A Reply to Messrs. Loomis and Grant), 1 J. COMP. CORP. L. \& SEC. REG. 39 (1978). Japan has a securities statute that closely parallels the Securities and Exchange Act of the United States. However, the staff responsible for promulgating and enforcing the implementing regulations is very small compared to that of the SEC; many provisions of the statute are treated as inoperative; and the emphasis is on de facto screening of issuers by regulatory authorities rather than full disclosure. See Kunio Hamada \& Keiji Matsumato, Securities Transaction Law in General, in 5 DOING BUSINESS IN JAPAN §§ 1.02[1], 1.02[4][b] (Kitagawa ed., 1987); SEC INTERNATIONALIZATION REPORT, supra, at III-127-30.

The United States, in addition to having a set of regulations and an administrative apparatus that together solicit more information from issuers than do those of other countries, also has a liability system that prods more information out of issuers. The liability system in the United Kingdom, for example, is not as far-reaching. See SEC INTERNATIONALIZATION REPORT, supra, at III-116. 
from making poor trading decisions as a result of being uninformed. Little scholarly attention, however, has been paid to the corporate governance effects of such required disclosure. ${ }^{2}$ In analyzing these effects, this article concludes that required disclosure can improve corporate governance in important ways. Indeed, improving corporate governance, not investor protection, provides the most persuasive justification for imposing on issuers the obligation to provide ongoing disclosure.

Before delving further into this topic, it is important to define more precisely the terms "required disclosure" and "corporate governance." "Required disclosure," as used in this article, means any legal obligation that requires an issuer's management to provide, on a regular basis, information that it otherwise might not be inclined to provide. ${ }^{3}$ In the United States, the primary source of required disclosure is the periodic disclosure requirements imposed on publicly traded companies under the Securities and Exchange Act of 1934 ("Exchange Act"). ${ }^{4}$ Other sources of required disclosure include the law of the issuer's state of incorporation, the rules of the stock exchange on which the issuer's shares are listed, and the issuer's articles of incorporation. ${ }^{5}$ The term

2. One notable exception is Louis Lowenstein, Financial Transparency and Corporate Governance: You Manage What You Measure, 96 COLUM. L. REV. 1335 (1996).

3. There are several reasons why an issuer's management might not want to produce information if it were under no legal obligation to do so. Disclosure might be helpful to competitors, major suppliers, or major customers. Both positive and negative information can help a potential acquirer of the issuer to better understand the issuer's business, and hence decrease the risk the acquirer would incur in a hostile tender offer. See infra Part V.A. Negative information can make management look bad and increase the risk of ouster by a hostile takeover or proxy fight - a threat that, if postponed through non-disclosure, might be eliminated by subsequent good news. Negative information can also injure the public reputations of managers and, with it, their sense of self-worth. See infra Part VI. If management thinks that a leveraged management buyout might be in its interests, positive information would increase the share price and make the buyout more expensive. Failures in the market for information, including "end game" problems and "market for lemons" problems, limit the usefulness of reputation alone as a method of policing this problem and create the need for a legal obligation. All of these points are discussed in considerably more detail in Merritt B. Fox, Retaining Mandatory Disclosure: Why Issuer Choice Is Not Investor Empowerment, 85 VA. L. REV. (forthcoming 1999).

4. Securities and Exchange Act of 1934, 5 U.S.C. \& 78a (1994). The reference here is to an issuer's obligations under the Securities and Exchange Act of 1934 to file Forms 10-K, 10-Q, and 8-K and an annual proxy statement pursuant to Schedule 14A. Required disclosure is different from the one-time disclosure associated with the registered offering of new securities.

5. By defining required disclosure in this fashion, this article focuses specifically on how required disclosure can impact corporate governance. This issue is separate from the debate about whether the source of the requirements ought to be a national or multinational authority, or whether an issuer should be able to choose the disclosure requirements, if any, under which it operates through its decisions of where to incorporate, where to list its stock, and which terms to include in its articles of incorporation. Commentators who believe that disclosure ought to be mandated by national statute include Lucian A. Bebchuk, Federalism and the Corporation: The Desirable Limits on State Competition in Corporate Law, 105 HARV. L. REV. 1435, 1490-91 (noting that the regulation of corporate disclosure under the authority of state corporate law rather than federal securities law would, because of regulatory competition, result in a suboptimally low level of disclosure); John C. Coffee, Jr., Market Failure and the Economic Case for a Mandatory Disclosure System, 70 VA. L. REV. 717 (1984); Frank Easterbrook \& Daniel Fischel, Mandatory Disclosure and the Protection of Investors, 70 VA. L. REV. 669, 684-85 (1984); Merritt B. Fox, Securities Disclosure in a Globalizing Market: Who Should Regulate Whom, 95 MiCH. L. REV. 2498 (1997); Fox, supra note 3. Commentators who believe that issuer choice, disciplined by market forces, is superior include Stephen J. Choi \& Andrew Guzman, Portable 
"corporate governance" refers to the myriad mechanisms that shape the structure of incentives, disincentives, and prohibitions under which an issuer's management makes decisions.

This inquiry will be confined in two respects. First, while disclosure can influence corporate governance in ways that impact a variety of interestsincluding labor, environmental quality, and the local community in which the issuer operates-the focus here will be exclusively on shareholder welfare. Second, the concern here is with the corporate governance of established issuers with shares actively trading in a public market and without a control shareholder or shareholder group.

II

\section{CORPORATE GOVERNANCE AS THE CENTRAL JUSTIFICATION FOR REQUIRED DISCLOSURE}

Required disclosure usually is justified as a way of providing investors buying and selling in the secondary market with protection comparable to what investors buying in the primary market receive through new issue registration disclosure. Contrary to popular belief, however, the main social benefit of required disclosure is its influence on corporate governance. ${ }^{6}$ Investor protection is a worthy goal of securities legislation, but it is not a persuasive justification for the affirmative regulation of issuer disclosure. ${ }^{7}$ Disclosure is not necessary to protect investors against either unfair prices or risk.

First, consider unfair prices. Under the efficient market hypothesis, security prices are unbiased, regardless of the amount of publicly available information about an issuer. ${ }^{8}$ In other words, share prices, on average, equal the actual

Reciprocity: Rethinking the International Reach of Securities Regulation, 71 S. CAL. L. REV. 903 (1998); Jonathan R. Macey, Administrative Agency Obsolescence and Interest Group Formation: A Case Study of the SEC at Sixty, 15 CARDOZO L. REV. 909, 922-27 (1994); Roberta Romano, Empowering Investors: A Market Approach to Securities Regulation, 107 YALE L.J. 2359 (1998).

6. The discussion in Part I is based on a portion of Merritt B. Fox, Rethinking Disclosure Liability in the Modern Era, 75 WASH. U. L.Q. 903 (1997).

7. This point is discussed in considerably more detail elsewhere. See Fox, supra note 5.

8. Empirical work showing unbiased reactions to announcements of corporate information suggests that the market is also unbiased to absences of comment by issuers about certain matters. This work consists of a large body of financial economics literature that evaluates the market's reaction to affirmative public announcements about various kinds of important events affecting particular issuers. For a classic review, see KENNETH GARBADE, SECURITIES MARKETS 249-59 (1982). The typical such "event study" involves a large number of issuers, each of which has experienced at one time or another the announcement of a particular kind of important event, such as a stock split. The studies show that the shares of the affected firms, as a group, experience statistically significant abnormal returns at the time of the announcement and, starting almost immediately thereafter, normal returns for the duration of the study, which is sometimes as long as several years. Thus, while some issuers' share prices go up in the periods following the announcement-compared to the market as a whole-and others go down, the average change is near zero. This finding suggests that as information diffuses to a larger and larger number of investors, the price, on average, does not change. Thus, the initial price reaction is, on average, the same as if this larger group of investors also knew the information as soon as it was released. The announcements of events tested in this fashion are similar to the types of information contained in Exchange Act filings. 
value of the shares involved regardless of whether issuers are required to produce substantial or minimal disclosure. Thus, greater disclosure is not necessary to protect investors from purchasing shares at prices that are, on average, unfair or higher than their actual values.'

Next, consider risk. With less available information about an issuer, the share price, while still unbiased, is less accurate; that is, the price is more likely to be significantly above or below the share's actual value. If an investor has a less-than-fully-diversified portfolio, greater share-price inaccuracy can make her portfolio more risky. High-quality disclosure, to some extent, would protect such an investor by reducing this risk. However, the investor can protect herself much more effectively and at less social cost by simply diversifying more. ${ }^{10}$

Thus, if required disclosure has a useful function, it is its influence on corporate governance. The discussion in Part III suggests that required disclosure plays an important role in this regard.

III

\section{REQUIRED DISCLOSURE'S ROLE IN ASSISTING THE EFFECTIVE EXERCISE OF THE SHAREHOLDER FRANCHISE}

The most obvious illustration of the influence of required disclosure on corporate governance relates to its ability to assist shareholders in effectively exercising their voting franchise. If shareholders are better informed when they vote for an issuer's directors, they are more likely to know whether their interests favor retention or ouster of the incumbents. The same is true of particular propositions subject to shareholder vote, such as amendment to the articles of incorporation, merger, or ratification of a transaction in which management has an interest. Such assistance, of course, is the explicit purpose of one form of required disclosure for U.S. issuers-the proxy rules under Section 14 of the Exchange Act-but the rationale of more knowledgeable shareholder voting is applicable to all forms of required disclosure.

A sophisticated observer might respond that this example ignores the realities of both the typical individual shareholder, who has only a tiny portion of the total number of outstanding shares, and the large shareholder, typically a wealthy individual or institution holding as much as a few percent of the issuer's outstanding shares. The sophisticated observer would argue that, in the case of the typical individual shareholder, the idea that disclosure assists voting rests on a mistakenly idealized view of shareholders as citizens, imbued with

9. For an analysis of why the noise theory critique of the efficient market hypothesis still does not create a strong fairness justification for mandatory disclosure, see Fox, supra note 5, at Part II.A.1.

10. In portfolio theory terms, issuer disclosure reduces firm-specific ("unsystematic") risk. Firmspecific risk can be completely eliminated by sufficient diversification. See Barbara Ann Banoff, Regulatory Subsidies, Efficient Markets, and Shelf Registration: An Analysis of Rule 415, 70 VA. L. REV. 135, 182 (1984). 
civic virtue, acting within a corporate democracy. In reality, all that is usually at stake in a corporate election is money. The behavior of the typical individual shareholder can be analyzed accordingly. To such a shareholder, the information made available by required disclosure is useless. Learning this information is not worth the effort, even if the information is placed in her physical possession for free. Moreover, there is only a minuscule chance that her vote will affect the outcome of the election, and in the unlikely event that it does, she receives only a tiny fraction of whatever gain her better informed vote brings about.

As for the large shareholder, the sophisticated observer would argue that required disclosure serves no important social function. Such a shareholder can make its own inquiries of the issuer's management, ask a wide range of searching questions, and make the appropriate negative inferences if it does not receive full answers. The information sought would be what the large shareholder believes is most useful at the time, rather than answers to a "one size fits all" set of government-mandated questions that are infrequently changed.

The sophisticated observer would be correct about the typical individual shareholder. He would be wrong, however, about the large shareholder. Some of the very same factors that cause the typical individual shareholder to find the information not worth learning actually help make required disclosure vital if large shareholders are to play their most socially useful role.

The essential distinction between the typical individual shareholder and the large shareholder is that the latter has a big enough stake that it would find it worth learning the kind of information produced by required disclosure. The problem is that the large shareholder is insufficiently motivated to acquire the information if it is not made freely available. Ideally, the amount of information that should be made available to each large shareholder would be the amount that a single owner of the same enterprise would want from an agent who is managing the enterprise. In a world without required disclosure, however, no large shareholder would be motivated to incur individually the costs of seeking out this amount of information. Huge collective action problems stand in the way. ${ }^{11}$ Each large shareholder's expected return from seeking out infor-

11. These collective-action problems are reviewed in Bernard S. Black, Shareholder Passivity Reexamined, 89 MICH. L. REV. 520 (1990). Professor Black correctly argues in his article that the problems described herein could be at least partly overcome by cooperative action among major institutional shareholders, if it were not for certain legal rules that chill such cooperation. That point, however, does not invalidate the description of required disclosure as a useful antidote to these collective-action problems. First, the existing legal regime continues to have such a chilling effect despite some recent ameliorating reforms to the proxy rules. Also, even if all rules with such a chilling effect were eliminated, the transaction costs associated with arranging the production and distribution of a public good, like information, would still make cooperation expensive and imperfect. Finally, Professor Black imagines a class of shareholders who cooperate in the absence of these chilling rulesinstitutions that hold a few percent of the shares of an issuer and can usefully cooperate in a small coalition to affect corporate governance. This class of shareholders is a subset of all the shareholders I have labeled as "large." A shareholder is large if it is big enough such that when it is presented with the information that required disclosure makes available for free, it finds the information at least 
mation is much less than that of the single owner dealing with a managing agent. Again, it is still far from certain that even the large shareholder's vote will affect the outcome of the election. Even if it does, the large investor would receive at most only a small percentage of any gain produced by the change in outcome. Substantial positive externalities exist when a large shareholder does receive information because the shareholder likely will exercise its franchise in a way that will enhance the interests of all shareholders. When these externalities are added up, it becomes cost-justified for each shareholder to receive the same amount of information from management as the single owner would want. ${ }^{12}$ Required disclosure can be seen, therefore, as a way of aggregating the demands of each large shareholder for information to be provided both to itself and to other large shareholders.

Two other considerations favor required disclosure over leaving it to each large shareholder to seek information for itself. First, because the same information is useful to all large shareholders, there are substantial economies of scale for the issuer to produce it all at once, rather than providing the information to each shareholder individually in response to the shareholder's particular requests. Second, in any country that prohibits trading on material, non-public information received from an issuer, the large shareholder faces an additional cost in making individual inquiries. If the shareholder receives any material, non-public information in response, it is prohibited from trading the issuer's shares until the information becomes public. Required disclosure solves this problem because the very method by which the information is provided makes it public.

\section{IV}

\section{REQUIRED DISCLOSURE'S ROLE IN ASSISTING SHAREHOLDERS TO ENFORCE MANAGEMENT'S FIDUCIARY DUTIES}

Required disclosure can also influence corporate governance by helping shareholders enforce management's fiduciary duties. Absent required disclosure, managers are not inclined to provide information that might suggest the existence of a breach of a fiduciary duty. Without that information, it is often impossible for shareholders to know about the potential breach.

Two examples illustrate this point. First, one focus of the Exchange Act's

worth the trouble of learning. For many issuers in many situations, the votes of large shareholders can, in the aggregate, change the outcome of an election, even though individually they are not big enough to be in the subset on which Black focuses.

12. One qualification is in order. A single owner, who can keep the information it receives from the issuer confidential, might want certain information that shareholders of a publicly traded issuer might not want because providing the information through required disclosure makes it public. Publicly provided information becomes available to the issuer's competitors, major customers, and major suppliers, thus potentially injuring the issuer. Mandatory disclosure imposed by a national government can be a solution to this problem, however, by putting all firms on an equal footing so that they would gain as much from the disclosure of others as they are hurt by their own disclosure. 
periodic disclosure rules is on issuer transactions in which managers have an interest. Once the existence of a conflict-of-interest transaction is known, shareholders can force management to satisfy its burden of establishing the validity of the transaction. To do this, management must show either that the taint of conflict has been removed by appropriate procedures in the transaction's authorization or, alternatively, that the terms of the transaction are clearly fair to the issuer. Without shareholder knowledge of such a transaction, the burden placed on management by corporate law is meaningless. Second, another focus of these disclosure rules is on segmented reporting, which requires a breakdown of issuer performance in each of its separate lines of business. With segmented reporting, it is much easier for a shareholder to detect a decision so poor as to suggest a violation of management's duty of care. Aggregate figures, which combine such a failure with the performances of ordinarily successful operations, are far less revealing.

The primary method for enforcing management's fiduciary duties is the shareholder derivative action. The derivative action is controversial, however, because of its "strike suit" potential. A strike suit is a non-meritorious action brought to blackmail management into a settlement so that management can avoid the costly process of continued litigation, particularly the costs of discovery. There is a tension in corporate law because it is often difficult to identify, before discovery, which suits are meritorious and which are not. Measures exist to reduce the derivative action's strike-suit potential by allowing easier dismissal before discovery; however, such measures are rather blunt instruments because they discourage both meritorious and non-meritorious suits. Without the current level of required disclosure in the United States, this tension would be much greater and the instruments much blunter, a point generally missed in the discussion of this controversy. Without required disclosure, most suitseven the ones against managers who did breach their duties-would inevitably start out as "fishing expeditions." The amount of discovery needed for shareholder's actions to perform any deterrent function would be much greater than is the case today and, if allowed, would greatly increase the number of derivative actions. The United States would be faced with the unenviable choice of foreclosing a larger number of meritorious suits or subjecting issuers to even more strike suits.

One could argue that required disclosure is not significantly helpful in assisting enforcement of fiduciary duties because management is unlikely to disclose information indicating the breach of such a duty, even if it is required to do so. Devices designed to ensure proper disclosure, including the required involvement of independent accountants, exaggerate this concern. To the extent that there is some truth in it, however, a second, related aspect of required disclosure remedies the problem. A breach of a required disclosure obligation, if ultimately detected, gives shareholders a cause of action under the securities laws that is often easier to pursue than the underlying corporate law claim. Required disclosure thus creates an additional deterrent against managers who 
breach their fiduciary duties in the first place.

\section{V \\ REQUIRED DISCLOSURE'S INDIRECT IMPACT ON CORPORATE GOVERNANCE}

The least recognized, but most important, influences of required disclosure on corporate governance are indirect. Required disclosure positively affects four of the economy's key mechanisms for controlling corporate management: the market for corporate control, share price-based managerial compensation, the cost of capital, and monitoring by external sources of finance. Through its effects on these mechanisms, required disclosure improves the selection of new investment projects in the economy and the operation of its existing productive capacity. $^{13}$

\section{A. The Market for Corporate Control}

The market for corporate control is a well-recognized device for limiting the agency costs of management where ownership is separated from control, as is the case with the typical publicly held corporation. More information, and the resulting increase in price accuracy, improves the control market's effectiveness in performing this role. In deciding whether it should buy a target that it thinks is mismanaged, an acquirer must assess what the target would be worth in its hands. This assessment is inherently risky, and acquirer management is likely to be risk averse. Greater disclosure, however, reduces the riskiness of this assessment. With greater disclosure, therefore, a smaller apparent deviation between incumbent management decisionmaking and what is needed to maximize share value to induce a potential acquirer to act would exist.

Also, when share price is inaccurately high, a potential acquirer, even though it is certain that it can manage the target better than incumbent management, may find the target not worth the price. The increased accuracy in share price resulting from greater disclosure reduces the chance that this will happen.

Greater disclosure thus makes the hostile takeover threat more real. Incumbent managers will be less tempted to implement negative net-present-

13. The discussion in Part V is based on a portion of Fox, supra note 6. See also Merritt B. Fox, Shelf Registration, Integrated Disclosure, and Underwriter Due Diligence: An Economic Analysis, 70 VA. L. REV. 1005, 1017-25 (1984); Marcel Kahan, Securities Laws and the Social Costs of "Inaccurate" Stock Prices, 41 DUKE L.J. 977, 985, 1006 (1992). For other perspectives on the efficiency-enhancing features of securities disclosure, see Edmund W. Kitch, The Theory and Practice of Securities Disclosure, 61 BROOK. L. REV. 763 (1995) (arguing that while regulators chase the goal of enhancing price accuracy, the laws enacted under this banner actually work to reduce the flow of information relevant to accurate pricing of securities); Paul G. Mahoney, Mandatory Disclosure as a Solution to Agency Problems, 62 U. CHI. L. REV. 1047 (1995) (arguing that the goal of disclosure should be focused on and limited to helping investors uncover breaches of contractual or fiduciary obligations); Lynn A. Stout, The Unimportance of Being Efficient: An Economic Analysis of Stock Market Pricing and Securities Regulation, $87 \mathrm{MICH}$. L. REV. 613 (1988) (disputing the premise that an efficient market is able to monitor or structure the allocation of scarce resources in the economy). 
value projects to maintain or enlarge their empires or to operate existing projects in ways that sacrifice profits to satisfy their personal aims. Those that nevertheless do these things are more likely to be replaced.

\section{B. Share Price-Based Managerial Compensation}

Greater disclosure can also reduce the agency cost of management by increasing the use of share price-based managerial compensation. ${ }^{14}$ The problem with share price-based compensation is risk. ${ }^{15}$ Because of the risk, managers who are risk averse will not want all of their compensation to be based on the firm's share price. ${ }^{16}$ More accurate share prices, which result from greater disclosure, make such compensation less risky. As a result, managers who are offered a total compensation package with a given expected value will be willing to take a larger portion of it in a stock price-based form.

\section{Capital Allocation}

Required disclosure, with its resulting increase in share-price accuracy, can also improve the selection of proposed new investment projects in the economy by directly affecting the investment behavior of individual firms. This effect is obvious when the project under consideration would be financed with a stock sale. The important point for this inquiry, given its focus on ongoing periodic disclosure, is that improved share-price accuracy can have a similar effect even when the firm finances the project some other way. On the supply side, share price can affect the cost of a project by affecting the terms at which intermediaries are willing to extend alternative forms of financing. ${ }^{17}$ On the demand side, share price can affect management's willingness to use funds to implement a new project in a couple of ways. It can affect management's willingness to use debt financing because of the prospect that the firm will subsequently counter-

14. Share price-based compensation is an affirmative way to better align the interests of management with those of shareholders. See, e.g., Michael C. Jensen \& Kevin J. Murphy, CEO IncentivesIt's Not How Much You Pay, But How, HARV. BuS. REV., May-June 1990, at 138. A critical review of the literature advocating greater share price-based compensation for management can be found in Merritt B. Fox, Insider Trading Deterrence Versus Managerial Incentives: A Unified Theory of Section 16(b), 92 MICH. L. REV. 2088, 2096-2106 (1994).

15. Job compensation is a large part of the typical manager's annual income. Therefore, a manager cannot diversify away the risk associated with receiving part or all of such compensation in share price-based form.

16. There is empirical evidence that a reduction in the riskiness of an issuer's stock will increase the proportion of stock-based compensation that a manager is willing to accept. Randall Kroszner compared the percentage of shares owned by officers and directors in a representative sample of exchange-listed U.S. firms in 1935 and in 1995, and found that the percentage increased from $13 \%$ to $22 \%$. See Randall Kroszner, Were the Good Old Days that Good? Evolution of Managerial Stock Ownership and Corporate Governance Since the Great Depression, Presentation at the University of Michigan Department of Economics History Seminar (Oct. 8, 1996) (unpublished manuscript on file with author). He found that the relationship between ownership and performance is very similar in the two periods and that the most promising explanation of the change is the reduction in stock price vol atility between the first and second periods.

17. See Homer KRIPKE, THE SEC AND CORPORATE Disclosure: Regulation In SEARCH OF A PURPOSE 123 (1979). 
balance any new debt with new equity financing to maintain its optimal debt/equity ratio. ${ }^{18}$ More generally, because of concern with public perceptions, low share price can constrain the use of both external and internal funds. $^{19}$

Combining the supply and demand factors, if share price is inaccurately low, management may decide not to pursue relatively promising proposed investment projects. If it is inaccurately high, it may implement relatively unpromising proposed projects. Required disclosure, through its enhancement of price accuracy, limits this problem.

\section{Reducing the Disincentives for Using External Finance}

Required disclosure can reduce a managerial bias toward choosing internal over external finance. As discussed below, use of external finance has a favorable impact on corporate governance, so a reduction in the bias for internal finance is socially beneficial.

In the United States, as in most countries, the sale of publicly issued securities requires a disclosure-based registration of the offering. This process involves disclosure of some information that managers would rather not produce, which is why the disclosure must be mandatory. By funding new projects with internally generated funds, managers can avoid these requirements. This option is a gain to them, but only if they do not need to disclose the same information for some other reason. Required disclosure could provide such an alternative reason. The more such information must be disclosed pursuant to required disclosure, the smaller the incentive to avoid outside finance based on a reluctance to disclose information.

External finance favorably impacts corporate governance because it forces managers to subject their real investment choices to the discipline and scrutiny of the market. ${ }^{20}$ Such scrutiny can have a very beneficial effect. Studies show that the investment projects chosen by firms relying predominantly on internal finance are considerably inferior to those chosen by other firms, an inefficiency which significantly damages the economy's growth and productivity. ${ }^{21}$

18. Some financial theorists suggest that there is no optimal debt/equity ratio. For the classic statement of this view, see Franco Modilgiani \& Merton H. Miller, The Cost of Capital, Corporation Finance and the Theory of Investment, 48 AM. ECON. REV. 261 (1958). The more orthodox view today is that there are factors weighing against both too little debt and too much. Too little debt deprives a firm of its tax-deductible interest payments. Too much debt leads to increased agency costs because it causes an increased divergence between the interests of debt and equity. It also increases the likelihood of bankruptcy, which would involve real costs. For an overview of these points and the responses of the adherents of financial structure irrelevance, see RICHARD A. BREALEY \& STEWART C. MEYERS, PRINCIPLES OF CORPORATE FINANCE 447-66 (5th ed. 1996).

19. See MERRITT B. FoX, FINANCE AND INDUSTRIAL PERFORMANCE IN A DYNAMIC ECONOMY: THEORY, PRACTICE, AND POLICY 282-87 (1987).

20. See Frank H. Easterbrook, Two Agency-Cost Explanations of Dividends, 74 AM. ECON. REV. 650, 654 (1984); Fox, supra note 19, at 132-40.

21. See, e.g., Gordon Donaldson, CORPORATE DeBt CAPACITY (1961); William J. Baumol et al., Earnings Retention, New Capital and the Growth of the Firm, 52 REV. ECON. \& STAT. 345 (1970). 
The hostile takeover activity of the late $1980 \mathrm{~s}$ can be viewed as a reaction to this problem. It was concentrated in industries in which firms had large free cash flows. ${ }^{22}$ In such cases, the objective of the acquirer often was to undertake a leveraged financial restructuring of the target to increase the payout of cash flows to the market. Alternatively, the goal was to "bust up" the target by separating, into different corporations, operations producing high cash flows from operations being inadvisably financed by these cash flows.

The hostile takeover boom may have partially corrected the problem of suboptimal projects funded by internal funds, but it entailed enormous transaction costs. With the subsequent spate of state anti-takeover statutes, hostile takeovers may be less effective at playing this role today. Required disclosure, by increasing what firms disclose as a matter of course, reduces the amount of additional disclosure needed when a firm publicly offers new securities. By reducing one of the disincentives for external finance, required disclosure can help alleviate the problem of poor investment projects much less expensively than hostile takeovers.

\section{VI}

\section{REQUIRED DISCLOSURE'S ROLE IN RAISING MANAGERIAL CONSCIOUSNESS}

Professor Louis Lowenstein has argued that required disclosure can improve managerial performance simply by forcing managers to become more aware of reality. ${ }^{24}$ Her argument is that required disclosure will favorably change managerial behavior in ways above and beyond the effects discussed above. Lowenstein states that a CEO's "capacity for denial is no less than ours.",25

When managers have the legal obligation to disclose certain information, they may have to gather and analyze information they would otherwise ignore. The proposition that this consciousness raising will lead to an improvement in shareholder welfare rests on two assumptions. First, without required disclosure, management will not gather and analyze all of the information that could, in a cost-effective fashion, help it pursue its own objective function. Second, the managerial objective function is sufficiently congruent with the best interests of shareholders so that if management, because of required disclosure, determines how to better pursue its objective function, the actions it will take will

For a critical review of these and several other studies, along with an estimate of the magnitude of the effects on the economy, see FOX, supra note 19, at 233-37.

22. See Michael C. Jensen, Agency Costs of Free Cash Flow, Corporate Finance, and Takeovers, 76 AM. ECON. REV. 323, 325 (1986); Reinier Kraakman, Taking Discounts Seriously: The Implications of "Discounted" Share Prices as an Acquisition Motive, 88 COLUM. L. REV. 891, 898 (1988).

23. See Michael C. Jensen, The Modern Industrial Revolution, Exit, and the Failure of Internal Control Systems, 48 J. FINANCE 831, 851-52 (1993).

24. See Lowenstein, supra note 2, at 1342.

25. Id. As examples of this kind of benefit, Lowenstein cites the testimony of officials from two European firms that their companies enjoyed managerial improvements as a result of submitting to the U.S. mandatory disclosure regime. See id. at 1357. 
also improve shareholder welfare. Both assumptions, though debatable, are plausible.

Despite the outside forces on management, few people would insist that management does not have at least some degree of slack. In other words, agency costs can be minimized, but not eliminated. Within this zone of slack, managerial behavior can be analyzed appropriately in accordance with the behavioral theory of the firm. ${ }^{26}$ Using this theory, it is easy to imagine that management might not gather and analyze certain kinds of negative information even though knowing the information would help management maximize its own objective function. ${ }^{27}$ Required disclosure, because of its "investor protection" emphasis on negative information, might help correct the problem.

For several reasons, management's objective function and the best interests of shareholders are reasonably congruent in relevant ways. A corporate manager, like anyone, can be expected to value compensation, perquisites, respect, power, affection, a sense of rectitude, and job security. The sources of these valued items are the firm's current and future cash flows, firm size, and firm growth. To maximize these sources, management must operate each of the firm's existing facilities to maximize the discounted present value of its cash flow and must identify, in rank order, as many promising new projects as possible for implementation. Both of these actions are ones that shareholders would want managers to undertake. ${ }^{28}$

It is certainly plausible that required disclosure could enhance management's ability to perform the first action, and there is no reason to believe that it would hinder its ability to perform the second. By revealing problems in existing operations that would otherwise be unreported, required disclosure can help management pursue its objective function-holding constant, for purposes of this part of the analysis, outside forces on management-and help shareholders at the same time. Reinforcing all of this, the typical manager's self es-

26. See, e.g., RICHARD CYERT \& JAMES MARCH, A BEHAVIORAL THEORY OF THE FIRM (1992); JAMES MARCH \& HERBERT SIMON, ORGANIZATIONS (1958).

27. See id. In these models of organizational behavior, a select subgroup of all the information potentially available to a firm is processed and evokes reaction. The selection and reaction is characterized by stable decision rules that have satisfied management's performance aspirations and will remain in effect until there is a failure to meet these aspirations. See id.

It is reasonable to think that the blind spots resulting from these rules of information selection can be shaped by, among other things, cognitive dissonance. See George A. Akerlof \& William T. Dickens, The Economic Consequences of Cognitive Dissonance, 72 AM. ECON. REV. 307, 308-09 (1982). In accordance with the behavioral theory of the firm, the consequence is that certain kinds of bad news will be avoided until, if ever, the practice of avoiding it leads to serious trouble.

28. The primary divergence between the managerial objective function and the best interests of shareholders develops where management cannot identify a sufficient number of projects with positive net present value to exhaust its current cash flow. In such a situation, shareholders would want the remaining cash flow paid out to them whereas management would want to retain it to fund additional projects. Managers of such a firm, as long as they can keep their jobs, gain from using these internally generated funds to implement any project that has a positive expected return, even if the project's expected return is well below what shareholders could earn on the money, that is, a negative net present value. See Fox, supra note 19, at 116-50. 
teem depends in part on her public image. Required disclosure, therefore, will make her try harder to avoid actions that will generate negative information.

\section{VII}

\section{NATIONAL DIFFERENCES IN MANDATORY DISCLOSURE}

Disclosure has costs as well as benefits. Given existing differences in firm governance structures among countries, there are likely to be important differences among issuers worldwide in the level of disclosure that will maximize the returns-net of the costs of this disclosure-from their capital utilizing, productive activities.

The decisions of a publicly held firm are the product of both its internal decisionmaking structure and the external environment that provides the inputs to make this structure function-most importantly for this analysis, shareholder votes and new capital. The internal, decisionmaking structure arises out of a combination of the law of the jurisdiction of incorporation and the issuer country's traditional business customs and practices. ${ }^{29}$ The external environment is determined by a number of factors including the degree of concentration of share ownership, the nature of the holders of any concentrated blocks, the rules and practices under which these holders use their voting power singly and in cooperation with others, the extent to which the legal system and suppliers of finance facilitate or hinder hostile takeovers, and the relative availability of financing in different forms-equity versus debt-and from different sourcesprivate versus public markets.

Comparative corporate governance has become an important subject for legal and financial scholars in recent years, and the resulting studies show significant contrasts among countries in both internal decision structures and external environments. $^{30}$ These contrasts indicate differences in the extent to which required disclosure will be effective in helping to align managerial and shareholder interests and in assuring the best choice of real investment projects. That, in turn, implies that one country's optimal level of disclosure may be higher than another's-optimal being defined as the level at which the required disclosure's marginal benefits equal its marginal costs.

To illustrate, a set of rough contrasts can be made between the United States, Canada, and, to a lesser extent, the United Kingdom on the one hand, and Germany and Japan on the other. The varying schemes in these countries suggest significant differences in the value of disclosure. In the United States,

29. Custom and practice include both the typical terms of the firm's articles of incorporation and how people typically behave within a given set of publicly and privately imposed legal constraints.

30. See, e.g., MARK J. RoE, Strong MANAGERS, WeAK OWNERS: The Political RoOTs OF AMERICAN CORPORATE FINANCE (1994); Bernard S. Black \& John C. Coffee, Jr., Hail Britannia? Institutional Investor Behavior Under Limited Regulation, 92 MICH. L. REV. 1997 (1994). An extensive review of the growing body of literature concerning this subject is found in Michael Bradley et al., The Purposes and Accountability of the Corporation in Contemporary Society: Corporate Governance at a Crossroads, 62 LAW \& CONTEMP. PROBS. 9, 49-76 (Summer 1999). 
voting power is less concentrated, and institutional investors are less inclined, separately or together, to exercise their voting power to influence corporate decisions. ${ }^{31} \quad$ In the United States, the United Kingdom, and Canada, debt/equity ratios are lower, ${ }^{32}$ and there is more use of publicly offered equity as a source of financing, ${ }^{33}$ particularly by relatively new companies financing major projects. Hostile tender offers are more frequent, as are solicitations of public shareholders in proxy fights. In contrast, in Germany and Japan, institutional investors play a larger role both in monitoring managerial behavior and in supplying finance, mostly debt. ${ }^{34}$

This comparison suggests that the optimal level of disclosure for U.S. issuers would be higher than for German and Japanese issuers. Institutional investors in the United States perform less monitoring of how managers of U.S. issuers make both operating and project choice decisions. They collect, analyze, and act on less information-both public and non-public-concerning these matters. Thus, more of the work of aligning managerial and shareholder interests with respect to these decisions falls to the hostile takeover threat and share price-based managerial compensation, both of which are assisted by greater public disclosure. Greater disclosure, and its enhancement of share-price accuracy, also aids good project choice in the United States because of the greater reliance by U.S. start-up companies on the public equity markets. ${ }^{35}$ The choice of required disclosure levels by these different countries conforms with this rough illustration. The United States and Canada require the most disclosure, Germany and Japan the least, with the United Kingdom somewhere in between. $^{36}$

31. See, e.g., ROE, supra note 30 , at $22,169-70$.

32. See, e.g., F.X. Browne, Corporate Finance: Stylized Facts and Tentative Explanations, 26 APPLIED ECON. 485, 488 (1994) ("[Non-financial] [f]irms in securities-based financial systems (the United States, the United Kingdom and Canada ... ) have quite low debt/equity ratios compared to those in the bank-based systems of Japan, Germany and France."); see also Bradley et al., supra note 30 .

33. See Browne, supra note 32 , at 494 (stating that external funding is significantly greater in the United States, the United Kingdom, and Canada than in Japan and continental Europe); see also Bradley et al., supra note 30 , at 51, 64-65.

34. Japanese firms borrow $\$ 5.33$ from banks for every dollar they raise in the capital markets; German firms borrow $\$ 4.20$, and American firms $\$ 0.85$. See Jonathan R. Macey \& Geoffrey P. Miller, Corporate Governance and Commercial Banking: A Comparative Examination of Germany, Japan, and the United States, 48 STAN. L. REV. 73, 85, 89 (1995).

35. Bernard Black and Ronald Gilson show that the availability of venture capital early in a firm's life is greatly facilitated by the prospect of a vibrant market for initial public offerings in the United States for issuers that have shown a certain degree of success. See Bernard S. Black \& Ronald J. Gilson, Venture Capital and the Structure of Capital Markets: Banks Versus Stock Markets, 47 J. FIN. ECON. 243, 246-64 (1998). This explains, according to them, why there is so much more venture capital available in the United States.

36. See supra note 1. 


\section{VIII \\ CONCLUSION}

This article demonstrates that required disclosure can play an important role in corporate governance. It assists shareholders in effectively exercising their voting franchise and enforcing management's fiduciary duties. It also affects positively four of the economy's key mechanisms for controlling corporate management: the market for corporate control, share price-based managerial compensation, the cost of capital, and monitoring by external sources of finance. In so doing, it improves the selection of proposed new investment projects in the economy and the operation of existing facilities. Finally, it may improve managerial performance simply by forcing managers to become more aware of reality.

All of this information can help identify the relationship between national differences in firm governance structures and their mandatory disclosure regimes. Disclosure has costs as well as benefits. Existing differences in firm governance structures from one country to another would suggest that the efficient level of required disclosure for firms of one country is not necessarily the same as the efficient level for firms of another country. In fact, countries whose firm governance structures suggest that disclosure would be of less valueGermany and Japan-have lower levels of mandatory disclosure than does the United States.

What is less clear is the cause of this observed relationship between disclosure and governance structures. Did differences in the amount of required disclosure lead to different national firm governance structures, or are the disclosure differences naturally efficient outgrowths of national governance structures that differ for other reasons? Would the introduction of U.S.-style mandatory disclosure in Germany and Japan lead to changes in their firm governance structures, and, if so, would the changes be desirable? If it would not lead to such changes, would it nevertheless improve, in a cost-effective way, the functioning of their current governance structures? This article is, at most, only suggestive in helping to answer these important questions, which are worthy topics of discussion and further research. 